\title{
Fra tugtemester til skolemester: Om forskelle mellem Luther og Grundtvig
}

\author{
Af Ove Korsgaard
}

Langt de fleste artikler, der gennem årene er skrevet om forholdet mellem Luther og Grundtvig, støtter den opfattelse, at der er dyb overensstemmelse mellem deres teologiske tænkning. Denne opfattelse problematiseres ved hjælp af en begrebshistorisk synsvinkel, der viser, at de brugte begreberne nation og folk med forskelligt betydningsindhold, hvilket indikerer, at de også teologisk på helt afgørende punkter tænkte forskelligt. Disse forskelle perspektiveres ved at se på Luthers kategorier 'lov og evangelium', 'husfader og husfolk' samt 'forældre og børn' med afsæt i Grundtvigs brug af 'knuden' som metafor.

Er Grundtvigs tænkning at betragte som en genuin overtagelse og videreførelse af Luthers? Eller er den nærmere at betragte som et opgør med Luthers tænkning? I virkeligheden kan der sikkert ikke svares generelt på spørgsmålet, da svaret afhænger af sagen og af indfaldsvinklen. Dog er der ingen tvivl om, at langt de fleste af de mange artikler, der gennem årene er skrevet om forholdet mellem Grundtvig og Luther, støtter den opfattelse, at der er dyb overensstemmelse mellem deres teologiske tænkning.

Når det gælder skabelsessyn, har Regin Prenter understreget sammenhængen mellem Luthers og Grundtvigs tænkning. Ifølge Prenter er det afgørende for Grundtvig at understrege, at hans egen tale om den bevarede gudbilledlighed ikke fører til en ophævelse af Luthers tanke om den trælbundne vilje. Prenter påpeger ligeledes, at der er sammenfald i tankegangen mellem Luthers tale om 'lov og evangelium' og Grundtvigs tanke om "menneske først, kristen så”. Grundtvigs udsagn skal ifølge Prenter forstås helt i forlængelse af Luthers. At være "menneske først" bliver følgelig ensbetydende med at se sig forpligtet af lovens fordring med erkendelse af, at en egentlig opfyldelse af loven er umulig. Samvittighedserfaringen af egen utilstrækkelighed over for loven udgør således forudsætningen for syndserkendelsen og tilegnelsen af evangeliets syndsforladelse. ${ }^{2}$

Når det gælder nadversyn, stiller Chr. Thodberg spørgsmålet: Var Grundtvigs nadversyn luthersk $?^{3}$ Ifølge Thodberg er Grundtvig svær at placere i forhold til de tre konkurrerende traditioner, den katolske, den reformerte og den lutherske. Han er ikke katolsk; han er ikke reformert; men han er heller ikke lutheraner, siger Thodberg. Han 
repræsenterer "det fjerde nadverstandpunkt ved siden af de tre allerede nævnte." ${ }^{4}$ Grundtvigs nadversyn bygger på, at det er ordet, der lyder ved alterbordet, som giver brødet og vinen sakral karakter. Den legemlighed, som brødet og vinen repræsenterer, er for Grundtvig allerede til stede $\mathrm{i}$ ordet. Ja, intet medium knytter en forbindelse mellem ånd og legeme som ordet. Men hvad med synet på altergang? Også her var der stor afstand mellem dem. Ifølge Luther skulle man gå til alters mindst fire gange om året for at opretholde sin ret til at bo i en kristen stat. ${ }^{5}$ Grundtvig derimod kæmpede hele sit liv imod, at man skulle til alters for sine borgerlige rettigheders skyld. Hvis man tager sit udgangspunkt $\mathrm{i}$ altergang og konfessionelle formuleringer, må der ifølge Thodberg svares nej på spørgsmålet: Var Grundtvigs nadversyn luthersk? Inddrager man derimod motiverne bag de positioner, som Luther og Grundtvig indtog, og ser dem i forhold til de forskellige problemstillinger, de kæmpede med i hver deres tidsepoke, må svaret snarere være ja. ${ }^{6}$

Svend Bjerg er nok den, der er gået længst i retning af at påpege stor afstand mellem Luthers og Grundtvigs teologi. Denne afstand kommer tydeligst til udtryk i Grundtvigs skrift Den christelige Børnelaerdom, der først udkom som en serie artikler i årene 1855-61. Den christelige Børnelaerdom er ifølge Bjerg skrevet som intet mindre end en slags konkurrent til Den lille Katekismus, som Luther skrev i 1529. Allerede i 1830 havde Grundtvig rejst spørgsmålet: Skal den lutherske Reformation virkelig fortscettes? I afhandlingen af samme navn er svaret, at reformationen naturligvis skal fortsættes, men på grundtvigsk manér. Grundtvig så sig selv som sin tids store kirkelige reformator. Som et af "Luthers ægte Børn" skulle han føre den lutherske reformation videre i Luthers egen ånd. Og personligt var han overbevist om, at "Morten Luther slet intet har imod saadanne Efterfølgere som jeg er". ${ }^{7}$ Den fortsatte reformation behøvede dog en anden indføring i den kristne børnelærdom, end den som Luther havde givet i Den lille Katekismus. Derfor skrev han Den christelige Børnelardom, som dog ikke havde børn som målgruppe, men voksne. I den forholder han sig overordentlig kritisk til flere sider af Luthers teologi. Grundtvigs mange kritikpunkter kan ifølge Bjerg samles under ét, da de reelt beskriver et principielt sammenstød mellem to teologiske normer,

på den ene side den grundtvigske trosbekendelse, på den anden side de lutherske sola-formler...., som siger, at frelsen beror på skriften alene uden traditionen, troen alene uden gerninger, Kristus alene uden menneskelige bisiddere. ${ }^{8}$ 
Regin Prenter, Chr. Thodberg og Svend Bjerg indtager således tre forskellige positioner til spørgsmålet om sammenhængen mellem Luthers og Grundtvigs tænkning: Med Prenter knyttes der en tæt forbindelse. Med Thodberg bliver der sagt både-og. Med Bjerg bliver der markeret stor afstand mellem Luthers og Grundtvigs teologi.

I denne artikel vil jeg også tage forholdet mellem Luther og Grundtvig op til nærmere behandling. Dog vil jeg ikke i første omgang gå videre ad det teologiske spor, men lægge en mere begrebshistorisk synsvinkel ned over dem, for dernæst at se på Luthers kategorier 'lov og evangelium', 'husfader og husfolk' samt 'forældre og børn' med afsæt i Grundtvigs brug af 'knuden' som metafor.'

\section{Nation - fra adel til folk}

Begrebshistorien bygger på den idé, at der er en sammenhæng mellem semantiske skift og samfundets strukturforandringer. Begrebshistorien er således en teoretisk og metodisk indfaldsvinkel til studiet af forholdet mellem ords betydningsændringer og de forandringer, der sker i den sociale kontekst. En samfundsmæssig transformation medfører sjældent, at der udvikles helt nye begreber; den indebærer derimod anvendelse af en række gamle begreber, der får ny betydning. Det gælder for eksempel de to begreber folk og nation. I tiden mellem Luther og Grundtvig fik de ny betydning. Det betød, at de brugte begreberne folk og nation med forskelligt betydningsindhold, og at de på helt afgørende punkter tænkte forskelligt.

Nation kommer af det latinske natio, der betyder fødsel og afstamning. I Rom blev ordet hovedsagelig brugt om grupper af udlændinge, der kom fra samme geografiske område, og hvis status - fordi de var udlændinge - var lavere end romerske borgere. Ordet blev ofte brugt $\mathrm{i}$ nedsættende betydning.

At ordet nation er blevet brugt på en anden måde end i dag, er Holbergs forfatterskab fra første halvdel af 1700-tallet et eksempel på. Han bruger for eksempel nation om en landsdel. "Jeg bær i særdeleshed en stor Kiærlighed til dend Jydske Nation." Han taler også om "den Jødiske Nation" og "den heele Nordiske Nation". Men hvad der i dag virker endnu mere fremmed er, at han omtaler medlemmer af en stand eller en art som en nation. Om lægestanden siger han: "her i Landet (er) den Medicinske Nation (:Lagerne) et fornemme Folk". Han bruger endog ordet nation om svin og hunde: "Intet incommoderer mig paa Landet uden Sviin og Hunde... men det er tvende Nationer, som man maa holde noget til gode, i Henseende til deres Nytte." Andre dyrearter har ifølge Holberg højere status. "De 
fornemste af den forsamlede Skare var en Leopard og en Tiger, hvoraf enhver var Hoved for sin Nation."10

I det følgende vil jeg kort pege på nogle af de grundlæggende betydningsskift, der er sket $\mathrm{i}$ brugen af begreberne folk og nation, hvilket samtidig indikerer grundlæggende strukturforandringer i samfundet. ${ }^{11}$

Nationsbegrebets udvikling kan, som den amerikanske nationalismeforsker Liah Greenfeld har gjort det, beskrives som en zigzagbevægelse, idet nye historiske omstændigheder har givet begrebet ny betydning. I middelalderen blev ordet nation brugt ved de nye kristne universiteter, der opstod rundt om i Europa. Her blev det anvendt som betegnelse for udsendinge og studenter fra forskellige geografiske sprogområder. Ved universitetet i Paris var studerende således inddelt i nationer, men begrebet nation havde her et andet betydningsindhold end i dag. Den franske nation bestod således af alle romansk-talende studenter fra Italien, Frankrig og Spanien; den germanske nation omfattede personer fra Tyskland, England og Skandinavien. ${ }^{12}$ Idéen om nationen som et fast geografisk baseret kulturfællesskab eksisterede ikke i middelalderen. Studenterne havde kun deres nationale identitet $\mathrm{i}$ kraft af deres status som studenter. Efter studierne identificerede de sig ikke med nationen. Gradvis kom ordet på universiteterne dog til at betyde mere end fælles afstamning, det begyndte også at referere til fælles synspunkter og hensigter.

Denne nye betydning fik afsmittende virkning på forståelsen af, hvem der repræsenterede universiteterne til kirkemøder. Det gjorde nationen. I middelalderen sendte universiteterne delegerede med meget høj status til de kirkemøder, der blev afholdt for at afklare og dømme i alvorlige gejstlige stridsspørgsmål. Efter kirkemødet i Lyon 1274 blev ordet nation anvendt som betegnelse for det "fællesskab af synspunkter", der eksisterede blandt de forskellige partier i "den gejstlige republik". Og dermed havde begrebet gennemgået en transformation: fra afstamning til repræsentation.

De talsmænd, der gav udtryk for nationernes synspunkter på kirkemøderne, besad imidlertid ikke kun teologisk sagkundskab, de repræsenterede også i stigende grad forskellige verdslige fyrster. Dermed gennemløb begrebet nation en ny transformation: fra religiøs autoritet til politisk autoritet. Nation kom i overgangen fra middelalder til tidlig moderne tid til at betyde en politisk, kulturel og social elite. Nationen blev et begreb for de politiske rettighedshavere, det vil sige de privilegerede klasser, der var repræsenterede ved stænderforsamlingerne. Når disse øverste medregerende stænder trådte sammen i 'parlamenter' eller 'landdage', repræsenterede de 'landet' - eller netop 
'nationen' - over for hoffet. ${ }^{13}$ Nationen var den politiske elite, mens folket var undersåtter.

Der eksisterede således 'nationer' før den moderne nationalisme, nemlig adelsnationer. Men fra og med det senere 18. århundrede blev 'adelsnationer' i stadig stigende tempo omformet til 'folkenationer'. ${ }^{14}$ Med denne transformation skete der en sammenforing af de to begreber, der kom fra hver sin ende af den sociale rangstige, nemlig nation og folk. Denne sammenføring medførte en kortslutning, der resulterede $\mathrm{i}$ en brand, som stadigvæk slår kraftige gnister fra sig, nemlig nationalisme. Liah Greenfeld peger som nævnt på, at denne kortslutning først skete i England og Holland, hvor begrebet nation i betydningen elite i 1500-tallet begyndte at blive brugt om landets befolkning og gjort synonymt med begrebet 'folk'. Men det var først med den franske revolution, at udviklingen i England og Holland så at sige blev 'forklaret'. I Frankrig resulterede sammenføringen af de to begreber nemlig $\mathrm{i}$ en gigantisk mutation i samfundets symbolske orden.

Der blev imidlertid ikke kun givet ét svar på spørgsmålet: Hvad er en nation? Ifølge Liah Greenfeld skete der med udgangspunkt i England endnu en transformation af begrebet nation, idet det i stigende grad blev anvendt om andre befolkninger og andre lande, som havde iboende politiske, territoriale og/eller etniske karakteristika. Som et resultat af denne proces blev 'et suverænt folk' til 'et unikt suverænt folk'. Denne ændring medførte en dybtgående forandring i selve nationalismens natur. ${ }^{13}$

Denne forskel er skyld i megen af den begrebsmæssige forvirring, der hersker i teorien om nationalisme. Den betød, at der på samme tid udviklede sig to forskellige opfattelser af begrebet nation, nemlig en politisk og en etnisk. De to opfattelser - med det samme navn udtrykker to forskellige former for national identitet og bevidsthed og to typer af kollektivitet. Mens man på engelsk og fransk gerne brugte begrebet nation synonymt med stat, adskilte man de to begreber i den tyske tradition. Her blev nation snævert forbundet med folk, om end adjektivet national fik en dobbeltbetydning, og kan henvise til såvel staten som til etniciteten. De forskellige former for nationalisme er udviklet af forskellige grunde. De fremkalder også forskellige mønstre i den sociale adfærd, i kulturen og i de politiske institutioner. Den vigtigste forskel vedrører forholdet mellem nationalisme og demokrati. Denne forskel vil jeg vende tilbage til. 


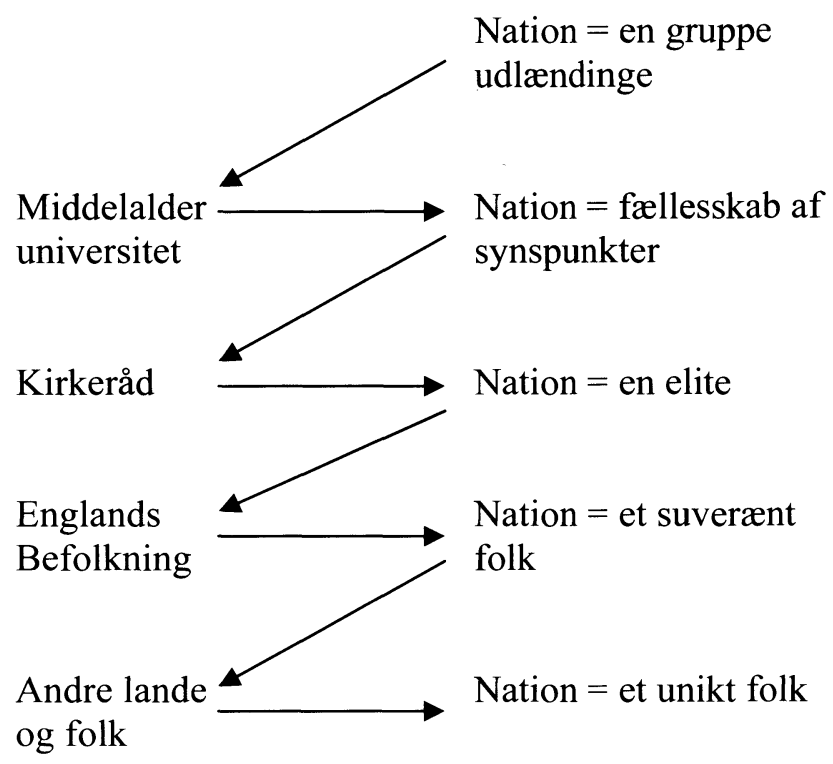

Transformationen af begrebet nation (efter Liah Greenfeld 1992)

Med hvilket betydningsindhold anvender Luther og Grundtvig begrebet nation? Luther bruger for eksempel ordet nation i skriftet $A n$ den christlichen Adel deutscher Nation fra 1520. I den henvendte han sig til den kristelige adel i det tyske rige for at få dem til at sammenkalde til et frit koncilium med det formål at reformere kirken, skolevæsnet og i særlig grad universiteterne. Her bruger Luther ikke ordet nation i dets moderne betydning, dvs. han knyttede ikke en forbindelse mellem begreberne nation og folk. Ifølge Greenfeld:

Yet he did not take the step that connected the separation from Rome to the definition of the polity as a people. The 'German nation', for Luther, had none but the conciliar meaning of the princes and nobility of the Empire, and in this sense he used it in An den christlichen Adel deutscher Nation. ${ }^{16}$

Selv om der under reformationen var tilløb til udvikling af en tysk nationalisme blandt tyske humanister, brugte Luther ordet nation i dets gejstlige og ikke i dets moderne betydning. ${ }^{17}$ Og dermed var Luther i overensstemmelse med den tyske adel, der ingen interesser havde $i$ at støtte en tysk nationalisme ved at identificere nationen med folket. Han havde ingen forståelse for moderne nationalisme med dens 
demokratiske overtoner. Formynderskab forblev Luthers politiske og pædagogiske horisont.

Grundtvig derimod har en anden forståelse af begrebet nation. Det kommer for eksempel frem i en skåltale for nationaliteten på det nordiske studentermøde den 30 . juni 1845 . Her fortæller Grundtvig om nationalitetsbegrebets transformation fra 1700-tallets kosmopolisme til 1800 -tallets nationalisme.

I forrige Aarhundrede, da jeg blev født, var man rask saa langt fra at oversætte Nationalitet ved Folke-Lighed, at man endog talte om den østerigske Nationalitet i Ungarn, i Bøhmen og Lombardiet, ja fandt det soleklart, at alle oplyste Folk maatte betragte sig som VerdensBorgere, der fandt deres Fædreneland, hvor de fandt deres Brød, og kunde gjøre hvilket som helst Sprog de behagede til deres Modersmaal!

Men ifølge Grundtvig var det ikke en lykkelig tid. Tværtimod.

Det var en tragi-comisk Tid, da man maatte baade lee og græde over den Troskyldighed, hvormed det forsikkredes, at al naturlig Forskjellighed hos Menneskenes Børn, enten som Folkefærd eller Enkeltmænd, var, ligesom Adel, kun en Lyd, saa man behøvede kun at være født i Paris for at være saa ægte en Franskmand, som man fandt under Solen, ja, man behøvede kun at indføre det franske Sprog ved Hoffet eller den franske Constitution i et Land, for at gjøre alle Slags Folk, selv Jyder, til ægte Franskmænd. ${ }^{18}$

Ud over at feje oplysningstidens kosmopolitiske forestillinger af bordet peger Grundtvig på, at det i slutningen af 1700-tallet endnu ikke var almindeligt at oversætte nationalitet ved folke-lighed. Det var først i 1800-tallet, at der knyttes en ubrydelig forbindelse mellem begreberne folk og nation. Hvad han ikke direkte peger på er, at han sikkert er den person, der i Danmark har haft størst betydning for få knyttet den samfundsomformende og identitetsskabende forbindelse mellem disse begreber.

\section{Folk-fra husstand til nation}

Slår man op i Nudansk ordbog defineres nation og folk som synonyme begreber. Slår man derimod op i ordbøger over det gamle danske sprog knyttes de to begreber ikke sammen. Ligesom ordet nation har ændret betydning, har ordet folk det også. Ifølge ordbog over Det gamle norske Sprog blev ordet folk brugt om "Husfolk, de Mennesker, som ere i ens Hus, høre til ens Husholdning", samt om "beslægtede Mennesker, Personer som tilhøre ens Slægt eller Ætt”. I Otto Kalkars ordbog til Det aeldre danske Sprog (1300-1700) gives der ligeledes eksempler på betydningsforbindelsen mellem folk, husstand og slægt: 
"mit folck og faders huus med fædre, slegt og mødre, min første folkefær, tipfader, oldermand." Hvad der springer i øjnene er, at i ordbøger over henholdsvis det gamle norske og danske sprog forbindes begrebet folk ikke med begrebet nation, men med slægt og husstand. I Det Kongelige Danske Videnskabernes Selskabs Dansk Ordbog, hvis første bind udkom i 1793, er den første definition på begrebet folk: "Person, som høre til én Slægt eller Folkefærd; en familie." Den anden: "Et Huses Folk; Forældre, Børn og Tyende." Denne forståelse gør sig stadigvæk gældende i midten af 1800-tallet, hvilket fremgår af C. Molbechs Dansk Ordbog, 2. udgave fra 1859, hvori begrebet folk defineres på følgende måde: "Personer, som udgiøre én "Familie, høre til ét Huus (...) I særdeleshed Tyende, Tienstefolk i et Huus".

Begrebet husstand har en lang betydningshistorie, der går tilbage til den antikke tænkning, hvor oikos er det græske ord for husstand. Et oikos er en familie med en husfader i spidsen og med slaver som tjenende medlemmer. I indledningen til sin Statslaere fremgår det klart, at Aristoteles betragter oikos som grundstenen i polis. Han siger således, at polis består af oikai. Direkte oversat betyder det, at "byen består af huse". Og disse huse udgør en social og økonomisk enhed. Den antikke tænkning om samfundet er således baseret på en todeling mellem oikos og polis.

Denne græske betydning af oikos kan genfindes i Hans Mossins Dansk Terminologie fra 1764, hvori det hedder, at "Husstanden er en stand i hvilken det eene kiøn forenes med det andet, til at leve tilsammen, for at genføde og opdrage "Børn, og arbeyde til fælles Hielp og Underholdning". ${ }^{19}$

Samfundets mindste grundenhed var ikke individet, men husstanden. Den samfundsmæssige helhed bestod så at sige af et vist antal husstande. Hver husstand havde som øverste autoritet en husfader, der havde myndighed over sit folk. Skræddermesteren havde myndighed over de svende og lærlinge, der - sammen med børn og andre familiemedlemmer - indgik i husstanden. Et lands samlede husstande var underlagt en landsfader og indgik $\mathrm{i}$ hans hus, for eksempel det oldenburgske hus, det habsburgske hus osv. Den øverste herre var Gud Herren, og alle samfundets huse indgik $i$ sidste instans $i$ hans hus. Begrebet menighed har ifølge Kalkars ordbog over det gamle danske sprog frem til 1700-tallet en langt bredere betydning end i dag. Kalkar siger: menighed $=$ menhed, dvs. almenhed, og citerer Coldings Etymologikon, der skriver: "civitas, borgerskab, menighed".

Det er først i slutningen af 1700-tallet, at europæisk filosofi bryder med den antikke forestilling, at det sociale består af to sfærer, oikos og 
polis, hvor oikos er huset og polis staten. I stedet opdeles det sociale i tre sfærer: staten, markedet og det civile samfund. Der sker en dybtgående spaltning af polisbegrebet. Hvor det hos Aristoteles, Cicero og Luther betegner en enhed, kommer der en adskillelse af staten og det civile samfund. Tilsvarende sker der en forandring af det andet begreb, oikos, der også spaltes ud i henholdsvis markedet og familien. Mens det i oikos er husfaderen, der styrer husets økonomiske anliggender, flyttes økonomien ud til samfundssfæren, til markedet. Tilbage er den private sfære med en kernefamilie. I 1776 gav den skotske moralfilosof Adam Smith i Nationernes velstand en sammenhængende beskrivelse af den nye form for økonomi, hvis grundlæggende kendetegn netop var adskillelsen af husholdning og virksomhed.

Den nye forestilling, at det sociale ikke består af to sfærer - stat og husstand, men af tre - stat, marked og det civile samfund - fik også konsekvenser for begrebet folk. Som nævnt begyndte man allerede i England i 1500-tallet at bruge ordet folk synonymt med begrebet nation. Men det var forst med den franske revolution, at sammenføringen af de to begreber for alvor tog fart på kontinentet. I de mange ordbøger, der blev udgivet i Danmark i 1800-tallet, kan man følge, hvordan den gamle betydning, folk som husstand og slægt, taber terræn til fordel for folk som nation. Denne udvikling afspejler sig i det forhold, at en stribe 'folke'-ord begynder at glide ud i hverdagssprogets periferi. Det gælder en række 'mandskabsord' som for eksempel krigsfolk, hoffolk, bådsfolk, landfolk, bønderfolk, høstfolk, sognefolk, tjenestefolk osv. Enkelte bruges dog stadigvæk, for eksempel brandfolk og søfolk. Noget tilsvarende sker med en række ord, hvor folk bruges i betydningen stand. Det gælder for eksempel: folkehold, folkeløn, folkekøkken, folkebord osv. Skiftet fra husstand og slægt til nation afspejler således også sociale og erhvervsøkonomiske forandringer.

Men der sker ikke kun det, at en række gamle ord glider ud af sproget, nye 'folke'-ord vinder indpas. Disse ord deler sig i to grupper med hver sin betydning: en politisk og en kulturel. Den politiske betydning kommer frem i ord som: folkesuverænitet, folkevilje, folkestyre, folkeafstemning osv. Den kulturelle betydning kommer til udtryk i ord som: folkevise, folkeeventyr, folkedragt, folkedans osv. 


\begin{tabular}{l|l}
\begin{tabular}{l|l} 
Folk som stand \\
Folkekøkken \\
folkemad \\
folkebord \\
folkestue \\
folkelagen \\
folkeseng \\
folkehold \\
folkeskat \\
folkeløn
\end{tabular} & Folk som 'skare' \\
\hline husfolk \\
søfolk \\
bådsfolk \\
Føstfolk \\
Folk som ethnos & brandfolk \\
Folkeviser & hoffolk \\
Folkesang & sognefolk \\
Folkeeventyr & bønderfolk \\
Folkesprog & Folk som demos \\
Folkeminder & Folkevilje \\
Folkedans & Folkesuverænitet \\
& Folkeafstemning \\
& Folketing \\
& Folkestyre \\
\hline
\end{tabular}

Transformationen af begrebet folk

(Efter Ove Korsgaard 2004)

\section{Lutherdom}

Begrebshistorien bygger på et dobbeltperspektiv. På den ene side er det en historie om begrebernes forankring i ordene, på den anden side om begrebernes rolle $\mathrm{i}$ forandringen af den sociale kontekst. Tilsammen skal de to perspektiver tjene til at afdække 'grænser og horisonter' for historiske erfaringsrum og forventningshorisonter. Hos Luther er formynderskab den forventningshorisont, der præger hans brug af begreberne folk og nation. At Luther gik ind for politisk formynderskab som det bedste styringsprincip, er ikke bemærkelsesværdigt. Det gjorde så at sige alle i samtiden. Det epokegørende og revolutionære ved Luther er, at han gjorde op med paven som religiøs formynder. 
Dette opgør på det teologiske plan spiller sammen med udviklingen af et nyt politisk verdensbillede, der flytter magtens tyngdepunkt fra den katolske (universelle) kirkes centrum i Rom til de regionale territorialstater og til landfyrsterne. ${ }^{20}$ Luther personificerer bruddet med middelalderens politiske filosofi, der bygger på den såkaldte to-sværds-teori. Ifølge den havde paven og kejseren hver fået overdraget et sværd af Gud til at styre det kristne samfund. Til erstatning for to-sværds-teorien udviklede Luther to-regimente-læren, der bygger på en skelnen mellem det verdslige og åndelige regimente. Han gik således fra at tale om to magtinstanser, kejseren og paven, til at tale om to regimenter, et åndeligt og et verdsligt. Staten skulle tage sig af det verdslige og kirken af det åndelige regimente. Det skelsættende ved Luthers to-regimente-lære var, at der blev indført et anderledes skarpt skel mellem det åndelige og verdslige rige end hidtil.

Luther opfattede imidlertid ikke den verdslige øvrighed som en sekulær øvrighed. Staten skulle ikke opfattes som religiøs neutral eller som ikke-religiøs. Tværtimod: den verdslige stat er også skabt af Gud, og alle verdslige forhold indgår i Guds skaberplan. Øvrigheden skulle derfor være kristen og styre det verdslige område under ansvar over for Gud. Enheden mellem staten og kirken begrundede Luther i det forhold, at Gud står over dem begge. I det verdslige rige hersker Gud ved sværdets tvang, i det åndelige rige ved ordets magt.

I sine prædikener og øvrige skrifter beskæftiger Luther sig ofte med politiske og pædagogiske spørgsmål. For Luther var opdragelsens og uddannelsens mål at gøre folk egnet til at leve med bevidstheden om at være borger $\mathrm{i}$ to regimenter, det verdslige og åndelige. Kun på den måde kunne lov og orden sikres og freden opretholdes. Husstanden er nøgleenheden i det verdslige regimente, det er en social enhed, hvori de enkelte ikke er personer for sig selv men medlemmer af et fællesskab. Individuel frihed var ikke en del af Luthers politiske program. Hans formyndersamfund byggede ikke på individuelle og myndige samfundsmedlemmer, men på et fællesskab mellem overordnede og underordnede. Husstanden udgjorde det sociale rum, hvori der blev knyttet en forbindelse mellem den enkelte og den kristne stat.

Forbindelsen skulle endvidere styrkes gennem en kristen opdragelse, hvilket for eksempel klart kommer til udtryk i Luthers store interesse for det fjerde bud: Du skal cere din fader og din moder. I Den store Katekismus (1529) er hans gennemgang af dette bud langt den mest omfattende. Man skal ifølge Luther

indprente ungdommen, at den skal anse forældrene for at stå i Guds sted og tænke på, at hvis de også er ringe, fattige, skrøbelige og sære, er de dog fader og moder, som er givet os af Gud. ${ }^{21}$ 
På dette punkt kunne de kristne lære noget af romerne, idet de kaldte

herrer og fruer i huset for 'Patres et matres familias', dvs. husfader og husmoder. Også deres landfyrster og overherrer kaldte de 'Patres patriae', dvs. hele landets fædre. Det er til stor skam for os, der vil være kristne, at vi ikke også kalder dem sådan, eller i det mindste anser dem for det og ærer dem tilsvarende. ${ }^{22}$

Luther bruger ikke kun 'fader' og 'moder' om børnenes biologiske fædre og mødre, men om myndighedspersoner. I buddet ligger der et krav om at udvise lydighed mod øvrigheden. "Den, der nu er lydig, villig og til tjeneste med alt, hvad ærbødigheden kræver, han ved, at han behager Gud og før glæde og lykke til løn." Det fjerde bud indprenter lydighed mod ens herre og foresatte. "Hvad nu et barn skylder sin fader og moder, har også gyldighed for alle, som hører til husstanden. Derfor skal karle og piger passe på, at de ikke bare adlyder deres herrer og fruer, men gør alt, hvad de ved, man vil have dem til". ${ }^{23}$

Embedet som husfader indbefattede ret til at revse og udøve hustugt. Husfaderen havde imidlertid ikke kun rettigheder, han havde også pligter i forhold til sine undersåtter, for eksempel havde han pligt til at give husets børn og tyende en kristen opdragelse. Forsømte han sin pligt, kunne han blive straffet. Luther selv var forbillede i rollen som husfader. I fortalen til sin såkaldte huspostil skriver han: "Disse Prædikner har jeg Tid efter anden holdt i mit Huus for mit Tyende og øvrige Huusfolk, for som Huusfader ogsaa at giøre Mit for mit Tyende ved at undervise dem $\mathrm{i}$ at føre et christeligt Levned." Luther som husbond i sin husstand blev forbillede for en hel genre af opbyggelsesbøger og forskriftslitteratur - også blot og bart kaldet husfaderlitteratur.

Luther betragtede Den lille Katekismus som den vigtigste bog, han har skrevet. I den gav han en kort, ordnet fremstilling af kirkesamfundets lære. Den byggede videre på den gamle tradition for kristendomsundervisning, men den skabte en ny form for systematik. Det specielle ved Luthers katekismus var, at han begyndte med dekalogen, altså De ti Bud.

Her vil jeg kun kort se nærmere på, hvilke disciplinære sanktioner Luther anbefaler, hvis ikke folk vil lære De ti Bud, Trosbekendelsen og Fadervor. De skal i første omgang trues. De skal have at vide, at de ikke vil få adgang til sakramenterne og ej heller vil kunne få et barn døbt i kirken. Men hvad hvis trusler ikke er nok? Skal præsterne så tage tvangsmidler i brug? Problemet for Luther er, at ifølge hans egen teologi er tro en frivillig sag. Han fremhæver da også: "vi skal ikke tvinge nogen til troen eller til sakramentet, heller ikke fastsætte love 
om tid og sted". Hvad præsterne skal, er at prædike, så folk selv får lyst til at få sakramentet. Præsten skal prædike, så folk vil tigge og bede om lov "og ligefrem tvinge os sognepræster til at række dem sakramentet". ${ }^{24}$ Men hvad hvis lysten udebliver? Hvad hvis ikke folk ønsker sakramentet? Til dem skal man sige: "Den, der ikke søger eller ønsker sakramentet i det mindste omkring fire gange årligt, om ham må man befrygte, at han foragter sakramentet og ikke er nogen kristen. ${ }^{25}$ Luther synes her meget tæt på at underminere hjørnestenen $\mathrm{i}$ sin teologi: at tro er en fri sag, idet der sættes minimumstal på, hvad man må forvente af en kristen. Som minimum må man forvente, at en kristen går til alters fire gange om året. Her vover Luther sig frem med en objektiv målestok for subjektive forhold.

Men han gentager, at præsten ikke må "opstille nogen lov, sådan som paven", men må holde sig til at fremhæve "nytten og skaden, møjen og gavnen, faren og frelsen i dette sakramente". Hvis præsten forstår at udpensle, hvor afgørende det er for folk at få del i sakramenterne, vil de komme uden tvang. Men hvis folk ikke kommer frivilligt, "så lad dem fare og sig dem, at de, der hverken agter eller føler deres store elendighed og Guds nådige hjælp, tilhører djævelen”. Præsten må true med alskens ulykker, men ikke tvinge til lydighed, når det gælder tro. Frem for at give præster og prædikanter et magtmiddel i hænde, der kan bruges over for folk, der ikke vil deres eget bedste, giver Luther dem i stedet et tungt og byrdefuldt ansvar. Hvis ikke folk kommer frivilligt, er det nemlig præstens skyld! Han evner ikke at overbevise folk om deres eget bedste. Det er "din skyld, hvis de foragter sakramentet. Hvordan skulle de kunne lade være med at være dovne, hvis du sover og tier? Tag jer derfor vel i agt, sognepræster og prædikanter. Vort embede er nu blevet et andet, end det var under paven, nu er det blevet byrdefuldt og gavnligt". ${ }^{26}$ Ligesom præster og prædikanter skal true de folk, der ikke frivilligt gør, hvad de forventes at gøre, således truer Luther de samme præster og prædikanter. Hvis ikke de tager deres opgave alvorligt, kan man ikke forvente, at folk vil blive gode kristne. Præsten skal nu kunne indgive folk lyst til at 'tvinge sig selv'. Fra præsten skal der - via Kristus - 'strømme' lyst til folket.

Men præsten har altid den mulighed at bede den verdslige magt om at tage affære, hvis ikke det lykkes at vække lysten. De genstridige skal i sidste instans ikke kun trues med udelukkelse af kirken, men også af samfundet. Man skal fortælle dem, at forældre og husherrer vil nægte dem mad og drikke og "at fyrsten vil bortjage sådanne rå folk fra landet". ${ }^{27}$ Så selv om præster ikke har magt til at tvinge folk til alters, har fyrster magt til at tvinge de uvillige ud af landet. 
Det skarpe skel, som Luther trak mellem det åndelige og verdslige rige, er $i k k e$ - som det ofte hævdes i dag - et skel mellem staten og kirken, men kun mellem staten og 'den usynlige kirke'. I forlængelse af Augustin skelnede Luther nemlig mellem to kirker, den usynlige og den synlige. Kirken har både en ydre, institutionel og højest verdslig side, og en indre, usynlig og højst åndelig side. Som medlem af statslegemet har man pligt til at være medlem af den synlige kirke, det vil sige kirken som institution. Medlem af den synlige kirke giver dog ingen sikkerhed for frelse. Den synlige kirke kan ikke bestemme over forholdet mellem den enkelte og Gud. Derfor er medlemskab af den synlige kirke ikke nok til at sikre frelsen. Tro er nødvendig. Og tro er et personligt og eksistentielt anliggende. Med regimentelæren blev der således skabt et åndeligt frirum. Dannelsen af det enkelte individs moral og karakter var derimod underlagt det verdslige regimente.

Ifølge regimentelæren er der i sidste instans sammenfald mellem den synlige kirke og den politiske magt. Når Luther taler om forholdet mellem kirke og stat, har han derfor som forudsætning, at det er den synlige kirke, stater træder i forbindelse med, ikke den usynlige. Den verdslige øvrighed hersker over legemet, ikke over sjælene. Og selv om denne afgrænsning i praksis viste sig at være temmelig teoretisk, trak Luther alligevel en principiel grænse mellem det verdslige og religiøse, der pegede frem mod demokratiets frihedsrettigheder.

At Luther ikke selv - i modsætning til, hvad mange teologer hævder - advokerer for en sekularisering af samfundslivet, kommer tydeligt frem $\mathrm{i}$ hans forhold til pavekirken og jøderne. Luther kunne være utrolig vulgær i sin antipavelige polemik. Han benyttede sig gerne af rendyrket satire og grovkornet propaganda. Havde Luther det svært med pavemagten, havde han det endnu vanskeligere med jøderne og deres indflydelse på samfundslivet. Mens paven og hans folk var at betragte som frafaldne kristne, var jøderne slet ikke kristne. Og derfor var de (teo)logisk set et fremmedelement i en kristen stat. I skriftet $\mathrm{Om}$ jøderne og deres løgne fra 1543 stiller Luther spørgsmålet: "Hvad skal vi kristne nu stille op med dette jødernes forkastede og fordømte folk?" Han giver selv syv råd, der leder tankerne hen på nazisternes praksis i 1930'erne.

Luther var på ingen måde fortaler for et liberalt samfund med religiøs tolerance og religionsfrihed, han bidrog tværtimod til at skabe kraftfulde fjendebilleder. Luther producerede imidlertid ikke nationale fjendebilleder, men religiøse. Nok betød hans skarpe skelnen mellem det åndelige og verdslige regimente, at ingen kunne eller skulle tvinges til at tro. Mens trosfrihed $\mathrm{i}$ det åndelige regimente var som sagt langtfra ensbetydende med religionsfrihed i det verdslige regimente. 
Dette regimente var ifølge Luther et kristent regimente. For Luther var det ikke national kultur, men kristen religion, der skulle være samfundets kit. Afvigelser fra fælles religionsudøvelse betragtede han derfor med den største alvor, hvad jøderne som omtalt fik læst og påskrevet på en yderst kontant og brutal måde.

\section{Folkedom}

Grundtvig voksede op i et samfund, hvis verdenssyn var præget af Luthers tanker om kald og stand. Lutherdommen udgjorde ikke bare det selvfølgelige trosgrundlag for kirken, men også det moralske grundlag for staten. Grundtvig var imidlertid selv med til at revidere dette grundlag. Fra 1811 til 1815 regnes Grundtvig for at være ortodoks lutheraner og frem til 1825 for ivrig lutheraner, men herefter begyndte han at markere sig med ret så Luther-kritiske synspunkter, hvilket hænger sammen med, at han selv blev en af tidens førende talsmænd for det nye synspunkt, at det ikke var lutherdommen, men folkedommen, der skulle udgøre statens og skolens moralske grundlag.

Skiftet fra lutherdom til folkedom betød, at Grundtvig efter 1825 igen og igen henviste til fejl hos Luther og hans disciple. ${ }^{28}$ Han gjorde således op med tre centrale dogmer $\mathrm{i}$ lutherdommen. Det ene var skriftfundamentalismen. Frem for Skriften forankrede han trosgrundlaget i det levende ord i trosbekendelsen. Det andet var syndsfundamentalismen. Frem for den ortodokse lutherske tankegang, at mennesket i kraft af sin natur fødes som et syndigt væsen, fremhævede han, at mennesket blev skabt i Guds billede, og om end billedet blev sløret, blev det ikke gjort ugyldigt af syndefaldet. Det tredje var lutherdommens statsfundamentalisme. For Grundtvig var den alliance, som Konstantin den Store i 325 etablerede mellem staten og kirken, intet mindre end et stort syndefald i kirkens historie. Og dette syndefald havde Luther ikke gjort op med. ${ }^{29}$

I sit opgør med lutherdommen skelnede Grundtvig dog til en vis grad mellem Luther selv og hans virkningshistorie. "Efter nu i trehundrede Aar at have prøvet denne Lutherske Oplysning og seet dens Virkninger," er der ingen grund til at imponeres. Tværtimod, resultatet har været yderst deprimerende. Derfor er der behov for at fortsætte "Luthers Kæmpeskridt, og nærme os Maalet, som er den fuldvoxne Christus." ${ }^{30} \mathrm{Og}$ et sådan skridt måtte tages ved hjælp af en ny, folkelig reformation, der byggede på en klar skelnen mellem kirke og stat, og kirke og skole. Og dermed tilsluttede han sig den adskillelse af skolen og kirken, som oplysningstidens tænkere var de første, der begyndte at argumentere for. 
Grundtvigs forvandling fra ortodoks til kritisk lutheraner hænger sammen med hans opdagelse af det levende ords betydning. Med henvisning til det levende ord kunne han underminere skriftens betydning i kirken såvel som i skolen. I første omgang udviklede han den kirkelige anskuelse, at det ikke var Skriften, men trosbekendelsen, der udgjorde fundamentet for menigheden. Menighedens mundtlige overlevering ved dåb og nadver udgjorde "den ubrudte Kiæde", der forbandt nutidskirken med aposteltiden. Ifølge Grundtvig kunne trosbekendelsen i lige linje føres tilbage til Kristus, der havde udformet den i de 40 dage mellem opstandelsen og himmelfarten. I sit opgør med skriftfundamentalismen kom Grundtvig til at lægge grunden til en ny ordfundamentalisme. ${ }^{31}$

Grundtvig opdagede ikke kun det levende ords betydning for menigheden, men også for folket og folkeånden. I en artikel $\mathrm{Om}$ Kirkehistorie fra 1847 siger han om Luthers syn: "Samler vi nu den christlige Oplysning hos Luther i en Hoved-Sum, da bestaaer den deri, at kun den Helligaand, og intet Menneske eller nogen Stand, er Herrens Statholder paa Jorden." Hvad Grundtvig savner hos Luther, er forståelse for folkeånden og folket som Herrens statholder på Jorden. Skal Helligånden kunne røre hjertet, må folkeånden træde hjælpende til; og for at det kan ske

maa baade Evangeliet levende og frit forkyndes for alle Folk paa det Maal, de ere fødte i, den Hellige Skrift paa Modersmaalet ligge aaben for alle, og de Troende tiltale hinanden med Psalmer og Lovsange og aandelige Viser, ligeledes paa deres Modersmaal, saa der kan leges yndigt for Herren i Hjertet. ${ }^{32}$

Grundtvig støttede selvfølgelig Luther i hans opgør med paven som Herrens statsholder, men til forskel fra Luther, der kun ville vide af Helligånden som statholder, indsatte Grundtvig folkeånden som statholderens medarbejder. Dermed blev forholdet mellem Helligånd og folkeånd et særdeles vanskeligt teologisk problem, som jeg ikke vil gå nærmere ind på, men kun tilslutte mig Theodor Jørgensens synspunkt, at Grundtvig aldrig fik helt styr på problemstillingen, hvilket lejlighedsvis gav sig udslag i kras nationalisme. Hvis man skelner mellem en etnocentrisk og en polycentrisk form for nationalbevidsthed, var Grundtvig i sin substans polycentrisk i sin forståelse af dansk folkelighed, men der er ifølge Jørgensen også klare etnocentriske afvigelser, "der hænger sammen med den uafklarethed, vi måtte konstatere i spørgsmålet og forholdet mellem Helligånden og folkeånderne.,"33

Grundtvig ville styrke Helligåndens medhjælper via en ny slags skole, nemlig en folkelig højskole. Det er bemærkelsesværdigt, at Grundtvig lancerer højskoletanken i sit første egentlige politiske skrift 
Politiske Betragtninger med Blik paa Danmark og Holsteen fra 1831. At Grundtvig begynder at udvikle sin politiske filosofi og pædagogiske filosofi i samme skrift, er ingen tilfældighed. Spørgsmålet om samfundsdannelse involverer så at sige automatisk spørgsmålet om personlig dannelse. Mens Rousseau udfolder forbindelsen mellem politisk filosofi og pædagogisk filosofi i sine storværker: Samfundspagten og Emile, nøjes Grundtvig med at antyde en sådan i Politiske betragtninger. Men hvad han her antyder, udvikler han i større målestok og med stigende klarhed de næste par årtier.

Radikaliseringen af de nationale, demokratiske og forfatningsmæssige spørgsmål i Danmark og i videre forstand i Europa er den umiddelbare årsag til Grundtvigs entré i polissfæren, og den direkte anledning til, at han i 1830'erne og 1840'erne skriver en række skoleskrifter, hvori han argumenterer for nødvendigheden af at oprette en folkehøjskole. Grundtvigs højskoleideer kan således betragtes som et vigtigt biprodukt, der primært vokser ud af hans politiske og nationale engagement.

Transformationsprocessen fra kristen fyrstestat til demokratisk nationalstat krævede en afklaring af forholdet mellem religion, stat og politik. Hvilken form for forbindelse skulle der etableres mellem individ, stat og religion i et demokrati? Skulle kristendommen, der var dybt integreret i enevældens statsform, fortsat udgøre grundlaget for statens opdragelsespolitik? At løsne forbindelsen mellem staten og kirken rejste det samfundsetiske spørgsmål: Hvis ikke kristendommen, hvad skulle så udgøre statens normative grundlag? Skulle der fortsat undervises i kristendom i skolen? Eller skulle katekismusundervisningen afvikles som skolens kernefag? Var kristen tro i det hele taget en skolesag?

For Grundtvig var det yderst påtrængende spørgsmål. Efter at han $\mathrm{i}$ sine unge år havde kæmpet for at fastholde kristendommen som statens grundvold, ændrede han holdning. Og blev 'moderne'. Som åndelig reformator blev han talsmand for en radikal liberalisering af kirkelivet. I fortalen til Haandbog $i$ Verdens-Historien (1833) skrev han:

jeg har efterhaanden lært, at skielne skarpt mellem Kirke og Skole, Tro og Vidskab, Timeligt og Evigt, og indseer klart, at ligesaa kraftigt som den Christne Kirke maa tilbagevise ethvert Forsøg af Stat og Skole paa at omdanne den efter Tykke, ligesaa uberettiget er den til at paanøde enten Stat eller Skole en kirkelig Skikkelse. ${ }^{34}$

På sin tids kirkepolitiske præmisser gik Grundtvig nu ind for religionsfrihed, for forkyndelsesfrihed og for løsning af sognebåndene.

Grundtvigs nye opfattelse af forholdet mellem kirke, stat og skole medførte et opgør med den form for katekismusundervisning, der 
siden reformationen havde udgjort grundlaget for kirkens og skolens samfundsetiske dannelse. At tage det uhyre radikale skridt at afskaffe kristendomsundervisning skete først i de private skoler. Mens der i almueskolen skulle undervises i Den lille Katekismus, meddelte en grundtvigsk inspireret skoleleder på en privatskole på Christianshavn 1835, at "Skolen er ikke Stedet, hvor Troen skal meddeles Børnene; men dette maa nødvendigvis ske i Hjemmet". I overensstemmelse med den grundtvigske anskuelse betragtede skolelederen det ikke som skolens opgave at fore eleverne ind $i$ et kristent trosliv, men ind $i$ en historisk sammenhæng: "Hovedsagen i Skolen bliver Menneskeslægtens Historie som Livets Spejl." 35

Skolelærer Rasmus Sørensen, Venslev, der var en ledende figur i de gudelige bevægelser, protesterede og tog til genmæle i flere indlæg. Forældrene måtte stille den fordring til skolen, at den gav børnene en levende undervisning i kristendom. I artiklen Hvad er en luthersk catechetisk Skole? gjorde han gældende, at katekismusundervisningen skulle fastholdes i de offentlige skoler, idet "Troens Meddelelse og den catechetiske Oplærelse af Herrens Ord i Troen" altid har været og fremdeles er hovedsagen $\mathrm{i}$ hans skole, som han for ingen pris vil give afkald på. ${ }^{36}$

Rasmus Sørensens indlæg kaldte i 1836 Grundtvig frem med artiklen: Er Troen virkelig en Skole-Sag? Hans eget svar var, "at Troen, Gud skee Lov! slet ingen Skole-Sag er". I artiklen rettede Grundtvig et voldsomt angreb på resultaterne af 300 års religionsundervisning;

thi det er en vitterlig Sag, at baade i det Protestantiske Tydskland og hos os, hvor Religjons-Underviisningen gjennem tre Aarhundreder blev drevet skolemæssig, der var det langt fra, Troen Aar for Aar blev fastere og mere levende, tvertimod blev den bestandig dødere og mere vaklende, til den omsider i Skolen næsten almindelig gav Vantroen Plads. ${ }^{37}$

Dette er for Grundtvig en sørgelig, men uomtvistelig kendsgerning.

Grundtvig påpegede, at der var et misforhold mellem skolen som institution og troens egenart. At undervise i tro, kræver tro. Men da man ikke kan gå ud fra, at lærerne er troende, kan de ikke varetage en sådan undervisning. Han advarede mod at stille forventninger til, at nye pædagogiske metoder vil kunne ændre på dette forhold. Hvad han håber på er, "at alle fornuftige Folk snart vil enes om at frabede sig Religjons-Underviisning i de offenlige Skoler af alle Slags". Det er i bund og grund forkert "at lære Troen uden ad som en Lexe eller at udtvære og giennempidske den catechetisk". ${ }^{38}$ Grundtvig opfordrede 
med andre ord folk til at frabede sig religionsundervisning $\mathrm{i}$ de offentlige skoler.

Frem for at undervise i trossager skal skolen give en indføring i, hvad det vil sige at leve som anstændig borger i samfundet, "men det er eens baade for Christne og Jøder og Hedninger, og bør staae aldeles uden for Troes-Sagen". Grundtvig argumenterede for en ændring af formålet med konfirmationen. Frem for en 'kristen' konfirmation ville han have en 'borgerlig' konfirmation. Konfirmationen skulle ikke tage sigte på optagelse i menighedslivet, men - uden mindste hensyn til vedkommendes tro - på "Optagelse i Borger-Samfundet". ${ }^{39}$

Grundtvig anerkendte således jøderne som fuldgyldige borgere. Da det i 1819 kom til optøjer rettet mod jøderne i København og et par købstæder, tog han stærkt afstand fra disse begivenheder. I Mands Minde-foredragene 1838 omtalte han igen "de Pøbel-Opløb", der gik ud over jøderne, "for at ytre mit dybe Mishag med det hele Skrig mod det ypperste og gjennem snart to Aartusinder ulykkeligste Folk paa Jorden, som Jøderne efter min fuldeste historiske Overbevisning er". ${ }^{30}$ Grundtvig indtog her en holdning, der var diametralt modsat den, Luther gav udtryk for i sit skrift om jøderne. Grundtvig tilsluttede sig på ingen måde Luthers glæde over, at jøderne var blevet fordrevet fra en række kristne byer og lande. Han udtrykte tværtimod harme over, at de blev forfulgt.

Det var adskillelsen mellem religion og borgerskab, der lagde grunden til de sekulære statsdannelser, vi kender i dag. Kun på indirekte vis har Luther andel i denne proces. Grundtvig derimod bidrog til processen, uden at han dermed kan gøres til et orakel i dag. Mens han for mere end 150 år siden satte skel mellem borgerskab og religion, bidrog han samtidig til at knytte en tættere forbindelse mellem borgerskab og national kultur. Forenklet kan man sige, at Luthers horisont var en verden opdelt i religioner, og disse kunne være underopdelt $\mathrm{i}$ folkeslag, mens Grundtvigs horisont var en verden opdelt i nationer, og disse kunne være underopdelt $\mathrm{i}$ forskellige religiøse samfund.

\section{Loven som tugtemester eller skolemester}

Som afslutning vil jeg søge at perspektivere diskussionen om forholdet mellem Luthers og Grundtvigs tænkning ved at belyse et enkelt begreb, der siger noget afgørende herom. Og det er begrebet 'knude', som Grundtvig ofte bruger som en central metafor. En knude indikerer på den ene side, at noget er gået $\mathrm{i}$ hårdknude, og på den anden side, at knuden måske kan løses op. Det er derfor sigende, at Grundtvig bruger 
ordet knude om forholdet mellem de to grundkategorier i Luthers teologi, lov og evangelium.

Som omtalt $\mathrm{i}$ indledningen er det Regin Prenters opfattelse, at Grundtvigs syn på forholdet mellem lov og evangelium ligger $\mathrm{i}$ forlængelse af Luthers. At være "menneske først" er ensbetydende med at se sig forpligtet af lovens fordring med erkendelse af, at en egentlig opfyldelse af loven er umulig. Samvittighedserfaringen af egen utilstrækkelighed over for loven udgør således forudsætningen for syndserkendelsen og tilegnelsen af evangeliets syndsforladelse. Men som Anja Stokholm har peget på, er det en yderst tvivlsom fortolkning af Grundtvigs udsagn: Menneske først, kristen så. ${ }^{41} \mathrm{I}$ tidsskriftartiklen Moses og Jesus fra 1852 tematiserer Grundtvig det centrale lutherske forhold mellem lov og evangelium. Og det sker i et opgør med Luther. Ifølge Grundtvig nåede Luther ikke langt nok i forståelsen af forholdet mellem lov og evangelium. Han har ikke formået at løse "Haardeknuden". ${ }^{42}$ I opposition til Luther vil han have De ti Bud ud af katekismen. Ved at fastholde disse bud som en del af den kristelige børnelærdom har Luther ifølge Grundtvig gjort sig skyldig i en sammenblanding af loven og evangeliet. I Grundtvigs optik kan intet bud, end ikke det dobbelte kærlighedsbud, stilles i spidsen for den kristelige børnelærdom. I stedet må der henvises til dåben og trosbekendelsen.

Grundtvigs kritik af Luthers syn på forholdet mellem lov og evangelium eliminerer ikke spændingen mellem de to kategorier. Også Grundtvig kan tale om loven som en forberedelse til kristendommen. Det særlige ved Grundtvigs syn på loven er imidlertid, at han i stedet for at tale om loven som en tugtemester til Kristus taler om "Moses som 'Skolemester' for al Verden, som fører hvem der ønsker det til Jesus". ${ }^{43}$ Dette skift i synet på loven - fra tugtemester til skolemester er en nøgle til forståelse af Grundtvigs tænkning. Grundtvig betragtede loven som en "Oplysning som man frit benytter sig af, som man kan og vil". ${ }^{44}$ I den grundtvigske forståelse bliver loven således et middel til folkeoplysning. Det er med andre ord muligt at løse op for knuden mellem loven og evangeliet. ${ }^{45}$

Det er ikke kun knuden mellem lov og evangelium, det er muligt at opløse ved hjælp af oplysning, det samme gælder forholdet mellem formynder og undersåt, fader og folk, herre og slave. Grundtvigs samfundsfilosofi bygger på den opfattelse, at samfundsdannelse altid bygger på en vis enighed om det fælles bedste;

thi hvor en saadan Grund-Enighed ikke spores, der har aldrig dannet sig et Borgerligt Selskab, men kun en Herre-Stand og Trælle-Stand i skarp Modsætning, der vel tilsammentagne kan kaldes en Stat, men er 
dog ingenlunde, hvad vi her taler om, da i en saadan Kreds 'den Stærkestes Ret' unægtelig er Grund-Loven. ${ }^{46}$

Hvis ikke der er en vis enighed om 'det fælles bedste', går forholdet mellem den enkelte og staten $i$ hårdknude. Derfor er det for Grundtvig et hovedspørgsmål, om det er muligt at undgå knuden. Og hvis skaden er sket, om det da lader sig gøre at løse knuden på anden måde end med sværdet. Det er her, skolen kommer ind som en ny, betydningsfuld institution. Ifølge Grundtvig er skolens historiske opgave nemlig at løse den gordiske knude mellem staten og individet på anden måde end med magt.

Dette er Knuden, den Gordiske Knude i Menneske-Udviklingen, som hidtil i Grunden altid overhugges med Alexander-Sværdet, men maa nødvendig løses med Læmpe og med Taalmodighed, hvor Staten skal reddes, og ægte menneskelig Oplysning skride frem til Dagens Ende. ${ }^{47}$

Knuder skal ikke hugges over, men løses med lempe. For at løse knuden mellem den enkelte og staten skulle statsmæssig oplysning træde i stedet for sværdet. Senere talte Grundtvig hellere om folkelig oplysning og folket. Men forskellen er ikke stor. Staten og folket befinder sig inden for samme sfære i den universalhistoriske treklang. Folket er så at sige den moralske og kulturelle side af staten. Men hvad enten Grundtvig taler om statsmæssig oplysning eller folkelig oplysning, skal oplysning tjene det overordnede formål at løse knuden - uden at løse båndene - mellem den enkelte og staten, nationen og folket.

Grundtvig gør i skriftet Om Mennesket $i$ Verden fra 1817 opmærksom på, at slægten er en historisk kategori. Han var selv af den opfattelse, at slægten endnu ikke havde udlevet sig selv, om end han var overbevist om, at det kun var et spørgsmål om tid, før slægtslegemet ville gå i opløsning. Grundtvig vidste om nogen, at det er en farlig affære at løse knuder. Det kan føre til total opløsning. Derfor afstod han i 1817 fra selv at bidrage aktivt til denne proces:

jeg (seer) godt hvor Knuden giennem Historien vil løse sig, nemlig i Opløsningen af de Baand der sammenknytter Forældre og Børn, thi Baandene kan man see, men løse dem kan jeg ikke, og gjorde det vel heller ikke, om jeg end kunde, thi det er Slægtens ømme Stæd, hvis Undersøgelse den vel næppe overlevede, og skiøndt den er hardtad forældet, er den dog endnu ikke udlevet. ${ }^{48}$

Grundtvigs løfte om ikke selv at bidrage til slægtslegemets opløsning holdt han dog ikke. Han blev tværtimod en slags åndelig vejleder for mange af de mennesker, der forlod slægts- og husstandslegemet for at gå ind i nationslegemet. 
Man kan - populært sagt - sige, at Grundtvigs oplysningsprojekt går ud på at løse knuder. Med lys skal knuder fordrives. Dermed forskyder han Luthers kategorier: 'lov og evangelium', 'fader og folk' samt (delvist) 'forældre og børn', fra metafysiske til historiske kategorier.

At oplysning kan løse knuder, radikaliserer spørgsmålet: Hvad er oplysning? I 1784 havde Kant i indledningen til skriftet af samme navn givet sit berømte svar: "Oplysning er menneskets udgang af dets selvforskyldte umyndighed. Umyndighed er mangelen på evne til at betjene sig af sin forstand uden en andens ledelse". ${ }^{49}$ Kant og Grundtvig er begge oplysningstænkere. De er fælles om at betragte oplysning som historiens motor. Men hvor Kant henviste til forstanden: "Sapere aude! Hav mod til at betjene dig af din egen forstand! er altså oplysningens valgsprog", der var spørgsmålet om oplysning en mere kompliceret sag for Grundtvig. ${ }^{50}$ Det er nemlig ikke alle knuder, der kan løses ved forstandens hjælp. Nok skal vi som mennesker søge stadig større indsigt i menneskelivets gåder, men som kristne

maa vi dog opgive at blive os det kristelige Livs Evighed klarlig bevidst i denne Verden, baade fordi det kun er i fuldkommen Enighed med Herren og hele hans Menighed, at denne klare Bevidsthed kan oprinde, og fordi den er umulig, uden naar 'det indvendige bliver udvendigt'. ${ }^{51}$

Hvis fuldkommen oplysning ikke kun beror på forstand og fornuft, rejser spørgsmålet om oplysningens kilde sig på ny. I Statsmoessig Oplysning fremhæver Grundtvig, at det er svært at give en klar definition på, hvad oplysning er. Når man begynder at tænke på ordet oplysning, kommer man let til den konklusion, at der gives "saamange Oplysninger (...) som der er Hoveder med Øine i". ${ }^{52}$ Der er med andre ord lige så mange 'oplysninger', som der er mennesker. Altså hvert individ - sit lys! Men giver oplysning overhovedet mening, hvis oplysningsbegrebet individualiseres? Ja, på en vis måde siger Grundtvig;

thi netop da jeg var ved at fortvivle over de utallige 'Oplysninger', faldt det mig naturligviis ind, at da det træffer sig saa vel, jeg selv ogsaa har et Hoved med Øine i, saa er jeg dermed hjulpet, og veed meget godt hvad jeg selv siger, naar jeg taler om Folks Oplysning, veed nemlig, at det baade først og sidst er deres egen Oplysning, jeg mener. $^{53}$

Grundtvigs tiltro til, at folks oplysning først og sidst er deres "egen Oplysning", bygger på den opfattelse, at alle i ordet har adgang til oplysning om livet. Alle mennesker har i det "lille" ord del i det 
"store" ords logos. Det centrale skriftsted for Grundtvigs ord-teologi er Johannesprologen, hvis indledning I begyndelsen var logos ligger til grund for hele Grundtvigs oplysnings- og "forklarings"-program. "Man maa nemlig vide", skriver Grundtvig i Den christelige Børneloerdom, "at 'Logos' paa Græsk svarer til 'Ordet' paa Dansk". ${ }^{44}$

Grundtvig skelner imidlertid mellem logos og dia-logos. Mennesket har ikke direkte adgang til det store ords logos, men må klare sig med det lille ord, hvis sandhedsværdi skal afprøves gennem dia-logos, altså dialog. Den centrale kategori i Grundtvigs oplysningstanker er derfor vekselvirkning. ${ }^{55}$ Gang på gang fremhæver han betydningen af en levende vekselvirkning mellem for eksempel eleverne indbyrdes, mellem lærer og elev, mellem fortid og nutid, mellem himmel og jord, Gud og menneske. For Grundtvig er oplysning derfor ikke et absolut, men et relativt begreb. Verden kan ikke overskues fra et panoptisk punkt, men bliver nødvendigvis set med forskellige øjne. Sandheden træder altid frem i spillet mellem sandheder. Med et moderne begreb kan man sige, at oplysning for Grundtvig er et diskursivt begreb, et kampbegreb. Ingen kan påberåbe sig at sidde inde med den absolutte sandhed. Vi erkender stykkevis og delt. $\mathrm{Og}$ en sådan erkendelsesproces kræver ifølge Grundtvig tro.

Som Uffe Jonas har gjort opmærksom på, indebærer tro for Grundtvig langt mere end det, der ligger i ordets rent konfessionelle betydning. Troen er også den følelse, der foregriber ukendt betydningsindhold, og dermed åbner troen vejen for nye erkendelser. Troen er den følelsesmæssige antagelse af verdens fornuftige indretning. For Grundtvig er der en dyb forbindelse mellem troen på Kristus og menneskelig oplysning. Og logos er forbindelsesledet. ${ }^{56}$

For Grundtvig er "Logos-Lærdom eller Christo-Logi" to sider af samme sag. ${ }^{57}$ Kristendom har ikke kun med tro at gøre, men også med erkendelse og videnskab. I Den christelige Børnelardom inddrager han den kristne menigheds forhold til oplysning, videnskab og universitetet. Bogen munder ud $\mathrm{i}$ en forestilling om, at det måske kunne blive nødvendigt for Grundtvig og hans trosfæller at træde ud af folkekirken. Hvis det blev realiteten, måtte de oprette deres egen præsteskole, der dog ikke bare skulle være en "Kristelig Kirke-Skole", men en hel "kristelig Højskole", dvs. et universitet.

Det kristelige universitet skulle ingenlunde være

indskrænket til det nødvendigste daglige Behov, men være stilet paa at omfatte alle Kundskabs- og Visdoms-Skatte, der jo umulig kan være 'skjulte i Faderens og Vorherres Jesu Kristi Erkjendelse', uden at de ogsaa i Herrens Frimenighed, som til Slutning skal staa Maal med ham, maa komme for Lyset. ${ }^{58}$ 
Frimenighedens universitet skal "oplyse hele Synskredsen lige til Menneske-Aandens og Menneske-Livets yderste Grænser". ${ }^{99}$ På universitetet skal menigheden søge den størst mulige klarhed, mennesket kan få gennem videnskabeligt arbejde. Om end vejen kan være svær at se på grund af mørke, er målet klart: "Den kristelige Oplysning har derfor først naaet sit timelige Maal, naar Herrens Frimenighed har vundet samme Klarhed, som aabenbarede sig i 'Menneske-Sønnen' Vorherre Jesus Kristus". ${ }^{60}$ Oplysningens mål er med tiden at vinde "samme Klarhed" som har åbenbaret sig i Kristus. Ifølge Grundtvig skal den kristne (fri)menighed ikke nøjes med åbenbaringen, den skal også drive universalhistorisk forklaringsvidenskab. Det må være "en kristelige Oplysnings Maal at vise, hvordan alt timeligt klarlig har sin oprindelige Sammenhæng i Guds-Ordet fra Evighed, og hvordan det under Tidsløbet er samlet i Kristus Jesus og lever i hans Menighed". 61 Grundtvig fremhæver, at ligesom menigheden for troens skyld trænger til oplysning om menneskeaanden og menneskeordet,

saaledes trænger den ogsaa for sit kristelige Menneskelivs Skyld højlig til at oplyses om det menneskelige Folkeliv, dets Vilkaar og Øjemed, da det aabenbar er et Folkeliv $\mathrm{i}$ en højere Orden, den kristne Menighed, (...) skal fuldføre til Vorherre Jesu Kristi Dag. ${ }^{62}$

For Grundtvig befinder kategorierne tro og erkendelse sig således ikke på hver sin side af en afgrundsdyb kløft. De skal virke sammen, uden at smelte sammen. Forholdet mellem tro og erkendelse er ikke af metafysisk, men af historisk karakter. Begge kategorier skal tjene til at oplyse og forklare menneskelivet. Og hvis man frem for at adskille tro og erkendelse som en absolut fordring fastholder forskellen som en historisk udfordring, kan forskellen gradvist minimeres.

I Grundtvigs optik er opgaven at fjerne knuder ved hjælp af lys. "At begribe sig selv i Sandhed det er da det store Maal for den menneskelige Fornuft, Høiden af menneskelig Vidskab". ${ }^{63}$ Ifølge Grundtvig er vidskab det danske ord for "Viisdom, d.v.s. fuldkommen Erkien-" delse, umiddelbar Anskuelse, og med det høieste christelige Udtryk: Beskuelsen Ansigt til Ansigt". ${ }^{64}$

\section{Litteraturliste}

Bjerg, Svend (2002), Gud først og sidst - en loesning af Den christelige Børnelardom, København.

Bugge, K.E. (1965), Skolen for livet. Studier over N. F. S. Grundtvigs poedagogiske tanker, København.

Bugge, K. E. et al. (1983), N. F. S. Grundtvig: Statsmaessig Oplysning, København. 
DV I = Grundtvig, N. F. S. (1816), "Om det Philosophiske Aarhundrede", Danne-Virke, et Tids-Skrift, bind 1, København, (fotografisk genoptryk 1983), 107-130.

$D V$ II = Grundtvig, N. F. S. (1817), "Om Mennesket i Verden", Danne-Virke, et Tids-Skrift, bind 2, København, (fotografisk genoptryk 1983), 118-206.

Frandsen, Steen Bo (1996), Opdagelsen af Jylland, Den regionale dimension i Danmarkshistorien 1814-64, Aarhus.

Faedrelandet, Nr. 1926, 1.7.1845.

Grane, Leif (1992), "Den uberegnelige Luther: essays om en arv og dens forvaltning", Kirkehistoriske studier, 3. række, nr. 2, København, 63-73.

Grane, Leif (1993), Dr. Martin Luthers lille Katekismus (1529) i den danske folkekirkes bekendelsesskrifter, København.

Greenfeld, Liah (1992), Nationalism: Five Roads to Modernity, Cambridge.

Grundtvig, N. F. S. (1852), "Moses og Jesus" i Dansk Kirketidende, nr. 44, 705-716.

Grundtvig, N. F. S. (1994), "Politiske Betragtninger med Blik paa Danmark og Holsteen" i Grundtvig-Studier 1994 med noter ved Vagn Wåhlin, København, 16-58.

Habermas, Jürgen (2001), Politisk filosofi - udvalgte tekster, København.

Hansen, Aage et al. (1984), Holberg-ordbog: ordbog over Ludvig Holbergs sprog, bd. III, København.

Jeppesen, Morten Haugaard (1993), Immanuel Kant: Oplysning, historie, fremskridt, Århus.

Johansen, St. (1950), Bibliografi over N. F. S. Grundtvigs Skrifter II, 1837-1849, København.

Jonas, Uffe (1997), "Tiden før Selvet - Grundtvig og det historiske menneske" i Ove Korsgaard (red.), En orm - en Gud. Om mennesket $i$ verden, Odense, 153-205.

Jørgensen, Theodor (1988), "Treenighedsteologi og folkelighed" i Jens Holger Schjørring (red.), Menneske først, kristen så. Helge Grells Grundtvig-disputats til debat, Århus, 9-25.

Korsgaard, Ove (2004), Kampen om folket. Et dannelsesperspektiv på dansk historie gennem 500 år, København.

Larsen, Joakim (1984), Bidrag til den danske skoles historie, bd. 3, København.

Luther, Martin (1976), Den store Katekismus, København.

Luther, Martin (1999), Mod tyrken og jøderne, Tidehvervs Forlag, Skærbæk. 
Lyby, Thorkild C., (1993), "Reformationen - et opgør med Romideen?" i Jakob Steen Due og Jakob Isager (red.), Imperium Romanum, bd. 2, Århus, 321-44.

$M M=$ N. F. S. Grundtvig, Mands Minde 1788-1838. Foredrag over det sidste halve Aarhundredes Historie holdte 1838 (1877, København.

Mossin, Hans (1764), Forsøg til en Dansk Terminologie eller Beskrivelse over de Ord i det Danske Sprog, Som betegner de Ting, der henhører til Tanke-Kunsten og Moralen, Bergen.

Prenter, Regin (1951), Skabelse og genløsning, København.

Stokholm, Anja (2003), "Om forholdet mellem skabelse og syndefald hos Grundtvig og Luther", Grundtvig-Studier 2003, København.

Thodberg, Christian (1989), Syn og sang. Poesi og teologi hos Grundtvig, København.

US IV = Grundtvig, N. F. S. (1906), "Kirkens Genmæle" (1825) i Holger Begtrup (red.), Nik. Fred. Sev. Grundtvigs udvalgte Skrifter, bind 4, København, 395-429.

Ibid., "Om den sande Christendom" (1826), 442-518.

Ibid., "Om Christendommens Sandhed (1826-27), 519-723.

US VI = Grundtvig, N. F. S. (1907), "Old-Tidens Historie" (1833),

Nik. Fred. Sev. Grundtvigs udvalgte Skrifter, bind 6, 5-531.

US IX = Grundtvig N. F. S. (1909), "Om Kirkehistorien" (1847) i

Holger Begtrup, Nik. Fred. Sev. Grundtvigs udvalgte Skrifter, bind 9, København, 70-79.

Ibid., "Den christelige Børnelaerdom" (1855-61), 329-595.

$V U$ IV $=$ Grundtvig, N. F. S. (1943), "Er Troen virkelige en Skolesag?" i Georg Christensen og Hal Koch (red.), N. F. S. Grundtvigs voerker i Udvalg, bind 4, København, 140-144.

Zernatto Guido (1944), "Nation: The History of a Word", Review of Politics, 6/1944, 351-366.

\section{Noter}

Prenter 1951, $252 \mathrm{ff}$.

Jeg ser her bort fra, at Regin Prenters synspunkter ikke står uimodsagt.

For eksempel har Anja Stokholm (2003) på overbevisende måde rokket ved Prenters konklusion. Jf. Grundtvig-Studier 2003, 88-125.

Thodberg 1989, 296.

Ibid., 324.

Jf. Luther i Grane 1993, 106.

Thodberg 1989, 324.

US IX, 395. Se Bjerg 2002, 154. 
Bjerg 2002, 156.

De følgende afsnit om begreberne nation og folk er en let bearbejdet udgave af forskellige afsnit i disputatsen Kampen om folket. Et dannelsesperspektiv på dansk historie gennem 500 år (Korsgaard 2004). Holberg-ordbog, se Hansen 1984, spalte 1226.

I gennemgangen af nationsbegrebets udviklingshistorie støtter jeg mig i særlig grad til Zernatto 1944, 351-366 og Greenfeld 1992, 3-21.

På Lunds Universitet tilhører studenterne stadig en bestemt nation, alt efter om de kommer fra Skåne, Halland eller Bohuslen.

Jeg bygger her på Habermas 2001, 256.

Jf. ibid., 257.

Mens Greenfeld ser kategorien: "et unikt suverænt folk" som en, der tidsmæssigt følger efter kategorien: "et suverænt folk", er jeg tilbøjelig til at tolke den begrebs-historiske udvikling af de to kategorier som sideløbende processer. Jf. Korsgaard 2004.

Greenfeld 1992, 283.

Ifølge Leah Greenfeld slog Ulrich von Hutten, der under reformationen var den mest indflydelsesrige skribent ved siden af Luther, til lyd for national samling i kampen mod Rom. Frem for flere privilegier til aristokratiet advokerede han for national frihed. Jf. Greenfeld 1992, $281 \mathrm{f}$.

Fadrelandet, Nr. 1926, 1.7.1845. Cf. Frandsen 1996, 314 f. Grundtvigs tale, af Johansen betegnet Skaaltale for Nationaliteten, er gengivet ordret, antagelig efter manuskript, se Johansen (1950), 816, $274 \mathrm{f}$.

Mossin 1766-67.

Jf. Lyby 1993, 321-44.

Luther 1976, 61.

Ibid., 68.

Ibid.

Luther i Grane, 1993, 106.

Ibid, 106.

Ibid., 107

Ibid., 104

Grundtvigs opgør med Luther har ikke været genstand for en egentlig dybdeborende undersøgelse. Dog har Leif Grane (1992, 133-45) givet en fortrinlig introduktion til Grundtvigs syn på Luther. Det samme gælder Svend Bjerg $(2002,153-61)$.

Jf. Grane 1992, $144 \mathrm{ff}$.

US IX, 74.

Grundtvig afviser det eksegetiske Pavedømme i Kirkens Gienmoele 1825. I skriftet "Om Christendommens Sandhed" 1826-27 siger han videre: "Lød nu virkelig den christelige Troes-Bekjendelse blot paa, at Bibelen var en guddommelig Bog, da vilde jeg meget betakke mig baade for at hedde Christen, og for at forsvare den christelige Tro. (US IV, 534). I dette såvel som i skriftet "Om den sande Christendom" fra 1826 udvikler han sin opfattelse af trosbekendelsen som den ubrudte "Kiæde" og som udtryk for "de Christnes ældgamle, over al Verden bekjendte Tro" (US IV, 535). 
US IX, $73 \mathrm{f}$.

Jørgensen 1988, 23.

US VI, 12.

Cf. Larsen 1984, 121. Skolelederen var Cand. Theol. J. G. S. Jensen. $V U \mathrm{IV}, 140$.

Ibid., 141. Grundtvigs artikel er skrevet ind i en debat i tidsskriftet Nordisk Kirke-Tidende 1836-37. Debatten blev igangsat af student og grundtvigtilhænger Sigfried Ley, som havde skrevet et indlæg, hvori han krævede katekismusundervisningen fjernet. Derefter skrev Rasmus Sørensen et modindlæg, som Grundtvigs artikel er en respons på.

$V U \mathrm{IV}, 143$.

Ibid., $143 \mathrm{f}$.

MM, 473.

Stokholm 2003, $102 \mathrm{ff}$.

Grundtvig 1852, 706 .

Ibid., $709 \mathrm{ff}$.

Ibid., 711.

Også i Den christelige Børnelardom advarer Grundtvig mod at give loven, det være sig Moseloven eller Danske Lov, "et kristeligt Skin, og endnu mere vogte os for at omgjøre Kristi Evangelium til en saakaldt ny, kristelig Lov, der skal paatvinge vor Sjæl en kristelig Tænkemaade og vort Hjærte den kristelige Kjærlighed”. US IX, 427.

46 Bugge 1983, 52.

47 Ibid, 31 .

48 DV II, 179.

49 Jeppesen 1993, 71.

50 Ibid.

51 US IX, 427.

52 Grundtvig 1983, $67 \mathrm{f}$.

53 Ibid., 68.

54 US IX, 435. Grundtvig benævner ofte Jesus som logos, f.eks. i skriftet "Om den sande Christendom": "thi er Logos, som man jo paastaar, den guddommelige Fornuft, og er Jesus Christus, som Evangeliet vidner, Logos, da er er det aabenbar høistfornuftigt at tro paa Jesus, som den guddommelige Fornuft". (US IVs. 459).

Bugge 1965.

Jonas $108 \mathrm{ff}$. Svend Bjerg $(2002,17 \mathrm{f}$.) strejfer samme problemstilling. US IX, 435.

Ibid., 579.

Ibid.

Ibid., 581.

Ibid.

Ibid, 586.

$D V \mathrm{I}, 117$.

Ibid., 110. 